\title{
Metabolic Reduction of Chromium by Alveolar Macrophages and Its Relationships to Cigarette Smoke
}

\author{
Fernando L. Petrilli, Giovanni A. Rossi, Anna Camoirano, Marco Romano, Domizio Serra, \\ Carlo Bennicelli, Antonio De Flora, and Silvio De Flora \\ Institute of Hygiene and Institute of Biochemistry, University of Genoa; \\ and 1st Division of Pneumology, S. Martino Hospital, XIII USL, 16132 Genoa, Italy
}

\begin{abstract}
Pulmonary alveolar macrophages (PAM), obtained by bronchoalveolar lavage from 47 individuals, reduced hexavalent chromium [Cr(VI)] and decreased its mutagenicity. Their specific activity-mostly mediated by cytosolic, enzyme-catalyzed mechanisms-was significantly higher than in corresponding preparations of mixed-cell populations from human peripheral lung parenchyma or bronchial tree, or from rat lung or liver. At equivalent number of PAM, $\mathrm{Cr}$ (VI) reduction, total protein, and some oxidoreductase activities were significantly increased in smokers. No appreciable variation could be detected between lung cancer and noncancer patients. In rats, the $\mathbf{C r}$ (VI)-reducing activity of PAM preparations was induced by Aroclor 1254. Thus, alveolar macrophages provide crucial defense mechanisms not only by phagocytizing metals, but also by metabolically reducing $\mathrm{Cr}(\mathrm{VI})$. The epithelial-lining fluid (ELF) also displayed some $\mathrm{Cr}$ (VI) reduction. Together with already investigated metabolic processes occurring inside lung cells, these mechanisms are expected to determine thresholds in the pulmonary carcinogenicity of chromium.
\end{abstract}

\section{Introduction}

Epidemiologic studies and animal assays have demonstrated that some chromium compounds can behave as bronchial carcinogens $(1,2)$. Most studies using short-term experimental models have provided evidence that trivalent chromium $[\mathrm{Cr} \text { (III) }]^{1} \mathrm{com}$ pounds are inactive in cellular systems, while solubilized hexavalent chromium [Cr(VI)] compounds can produce a variety of gene and chromosomal mutations, as well as DNA-damaging and cell-transforming effects (1-4).

\section{Address correspondence to Dr. S. De Flora. \\ Received for publication 19 September 1985 and in revised form 14 January 1986.}

1. Abbreviations used in this paper: $2 \mathrm{AF}, 2$-aminofluorene; $\mathrm{BAL}$, bronchoalveolar lavage; $\mathrm{B}(\mathrm{a}) \mathrm{P}$, benzo(a)pyrene; $\mathrm{B}(\mathrm{a}) \mathrm{P}-7,8$-diol, benzo(a)pyrene trans-7,8-diol; CPA, cyclophosphamide; $\mathrm{Cr}$ (III), trivalent chromium; $\mathrm{Cr}(\mathrm{VI})$, hexavalent chromium; CSC, cigarette smoke condensate; DMSO, dimethylsulfoxide; DPC, $s$-diphenylcarbazide; ELF, epithelial-lining fluid; G6PD, glucose-6-phosphate dehydrogenase; ICR 191, 2-methoxy-6chloro-9[3-(2-chloroethyl)aminopropylamino]acridine $\cdot 2 \mathrm{HCl}$; $4 \mathrm{NQO}, 4-$ nitroquinoline- $N$-oxide; P.AM, pulmonary alveolar macrophage; PCB, polychlorinated biphenyl; pCMB, p-chloromercuribenzoate; 6PGD, 6phosphogluconate dehydrogenase.

J. Clin. Invest.

(c) The American Society for Clinical Investigation, Inc.

0021-9738/86/06/1917/08 $\$ 1.00$

Volume 77, June 1986, 1917-1924
In spite of its classification as a human carcinogen, there are several defense mechanisms in the organism, based on chemical or biochemical oxido-reductive processes, which tend to limit the possible target of chromium carcinogenicity and to constitute a threshold to its activity $(3,5-8)$. For instance, $\mathrm{Cr}(\mathrm{VI})$ is reduced in human plasma (9) and inside erythrocytes $(10,11)$, this being in agreement with the finding that chromium typically produces tumors at implant sites (1). Saliva and especially gastric juice are also quite effective in reducing $\mathrm{Cr}$ (VI)(12), thus constituting a hardly surmountable barrier to the metal introduced by the oral route or swallowed after reflux from the respiratory tract. In fact, $\mathrm{Cr}$ (III) is not capable of permeating mammalian cell membranes $(3,5)$ and is very poorly absorbed by the intestine (13).

Additionally, $\mathrm{Cr}(\mathrm{VI})$ is reduced by whole cell homogenates and subcellular fractions from a variety of tissues in different animal species $(6,11,12,14)$. The underlying biochemical mechanisms have been elucidated, at least in part, and ascribed to various reductive reactions occurring in mitochondria (15), in microsomes $(7,16,17)$, and in the cytosol, where reduction can be promoted by electron donors, such as reduced glutathione, and chiefly by NADH- and NADPH-dependent enzyme-catalyzed mechanisms, among which the DT-diaphorase activity (7).

Interestingly, these mechanisms can also be detected in lung cell preparations (7), where they appear to be stimulated not only by enzyme inducers but also by the repeated intratracheal administration of $\mathrm{Cr}(\mathrm{VI})$ itself to rats (6). Reduction of $\mathrm{Cr}(\mathrm{VI})$ has been obtained in the presence of various rat lung preparations $(6,7)$, and a decrease of its mutagenicity has been also shown to occur in the presence of a large number of samples of mixedcell populations prepared from human lung peripheral parenchyma or from bronchial tree (18).

We have now investigated whether $\mathrm{Cr}$ (VI) can be also reduced, before getting in contact with the target tissue, by the extracellular environment of the lower respiratory tract-the so-called epithelial-lining fluid (ELF)—and by pulmonary alveolar macrophages (PAM). These cells are well known to play an important role as defense mechanisms of the respiratory tract against inhaled foreign material (19) and have been demonstrated to interact with chromium also. In fact, this and other metals could be detected by $x$-ray analysis in cells of welders (20). Furthermore, particles coated with chromium were phagocytized at a faster rate by rabbit PAM (21), the intratracheal administration of chromates to rats resulted in an increase frequency of PAM foci (22), and their inhalation stimulated PAM phagocytic activity (23).

Samples of human ELF and various PAM preparations were investigated for their ability to reduce $\mathrm{Cr}(\mathrm{VI})$, also in comparison with preparations of other human or rat cells. The patterns of this reaction and other biochemical parameters were explored and related to smoking habits. In addition, its inducibility by 
Aroclor 1254, a polychlorinated biphenyl (PCB) stimulating a wide spectrum of enzyme activities and behaving as the most potent inducer of chromium metabolism in rat liver and lung cells (6), was evaluated in rat PAM.

\section{Methods}

Patients. Alveolar macrophages were obtained from 47 patients undergoing bronchoalveolar lavage for evaluation of localized, noninflammatory lung lesions. They were classified according to age, sex, disease, and smoking habits.

Animals. 40 male, adult Sprague-Dawley rats ("Morini" strain), weighing $\sim 300 \mathrm{~g}$, were used. The animals were divided into two groups and, $5 \mathrm{~d}$ before killing, they were treated with a single intraperitoneal injection of $200 \mu \mathrm{l}$ of either corn oil (controls) or of Aroclor 1254 (Monsanto Corp., St. Louis, MO) $(500 \mathrm{mg} / \mathrm{kg}$ body wt) diluted in corn oil.

Procedure of bronchoalveolar lavage (BAL). BAL was performed as previously described (24). Briefly, the trachea and upper airways of patients were anesthetized with xylocaine spray and a fiberoptic bronchoscope, having a 5-mm tip, was introduced through the nose and wedged in a third- or fourth-order bronchus. One or two segments were lavaged in each patient by infusing sterile isotonic saline in five $20-\mathrm{ml}$ aliquots, with a typical return of $40-60 \mathrm{ml}$ per each $100 \mathrm{ml}$ infused. In all cases, only dose portions of the lung free of disease, as evaluated by chest $x$ ray analysis and by bronchoscopic examination, were lavaged. The fluid was collected in plastic sterile containers in order to minimize adhesion of macrophages and kept at $4^{\circ} \mathrm{C}$. A small portion was used for cell count and for cell viability evaluation by trypan blue exclusion.

The remaining fluid was spun at $500 \mathrm{~g}$ for $5 \mathrm{~min}$ in a refrigerated centrifuge. The cell-free supernatant, containing diluted ELF, was collected and, for 15 patients, it was kept at $-80^{\circ} \mathrm{C}$.

The cell pellet was washed twice with a $50 \mathrm{mM}$ Tris- $0.25 \mathrm{M}$ sucrose

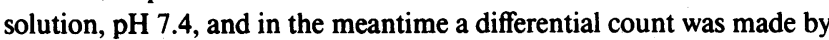
using a Giemsa-stained cytocentrifuge preparation (Cytospin). Samples containing $<90 \%$ macrophages were not used for this study. The other samples were resuspended at a concentration of $5 \times 10^{6} \mathrm{PAM} / \mathrm{ml}$ of Tris-sucrose and frozen at $-80^{\circ} \mathrm{C}$. The number of macrophages obtained from each patient varied, especially depending on smoking habits, from 4 to $25 \times 10^{6}$ for every segment lavaged.

Recovery of PAM was obtained in rats subjected to general anesthesia with ether. The lungs were perfused with heparinized $0.15 \mathrm{M} \mathrm{NaCl}$ and subsequently lavaged with five $10-\mathrm{ml}$ aliquots of sterile $0.15 \mathrm{M} \mathrm{NaCl}$, infused via a cannula inserted in trachea. Preparation of the PAM suspension was carried out as described for humans, with a mean recovery of $\sim 0.8 \times 10^{6} \mathrm{PAM}$ per animal. Due to this low recovery, all the samples collected within each one of the two groups of 20 rats were pooled together.

Preparation of PAM homogenates and subfractions. All steps were carried out at $0^{\circ}-4^{\circ} \mathrm{C}$, using sterile materials and operating under aseptic conditions. PAM suspensions were thawed and homogenized by means of a Polytron blender. When needed, homogenates were further processed by differential centrifugation, e.g., for $15 \mathrm{~min}$ at 2,000, 9,000, and 20,000 $g$, using a MLW K24 refrigerated centrifuge, and for $60 \mathrm{~min}$ at 105,000 $g$ using a Beckman Spinco L2-65B ultracentrifuge. Homogenates and subcellular fractions were either used immediately or kept at $-80^{\circ} \mathrm{C}$ for a maximum of $30 \mathrm{~d}$ before testing.

Part of the samples were tested individually in order to detect possible sources of variability of the parameters under monitoring. The remaining samples were pooled in groups, generally including the cell preparations from five individuals, and were used in experiments aiming at assessing the patterns and mechanisms of $\mathrm{Cr}(\mathrm{VI})$ reduction.

Preparation of postmitochondrial fractions from human or rat tissues. Liver S- 9 fractions were pooled from 5 of the 20 Aroclor-treated rats used for PAM collection and tested as controls of the metabolic system in mutagenicity assays. Liver and lung S-9 fractions, pooled from 5 of the 20 untreated rats (receiving corn oil only) used for PAM collection, were tested for their $\mathrm{Cr}$ (VI)-reducing activity, in comparison with human PAM S-9 fractions and with S-12 fractions of human lung. These were prepared at the CNR Institute of Clinical Physiology (Pisa, Italy) from samples of peripheral lung parenchyma and of whole bronchial tree pooled from five surgery patients.

Immediately after collection, rat or human tissues were washed in ice-cold $0.15 \mathrm{M} \mathrm{KCl}$, weighed, and homogenized in $3 \mathrm{vol}$ (wt/vol) of 50 $\mathrm{mM}$ Tris- $0.25 \mathrm{M}$ sucrose buffer, $\mathrm{pH} 7.4$, first in a Polytron blender and then in a Potter-Elvehjem homogenizer. The supernatants recovered after centrifugation for $15 \mathrm{~min}$ at $9,000 \mathrm{~g}$ (rat tissues) or $12,000 \mathrm{~g}$ (human tissues) were used as postmitochondrial fractions.

Chemicals and biochemicals. Sodium dichromate $\left(\mathrm{Na}_{2} \mathrm{Cr}_{2} \mathrm{O}_{7} \cdot 2 \mathrm{H}_{2} \mathrm{O}\right)$ was purchased from Merck-Schuchardt (Munich, Federal Republic of Germany). Other test mutagens included: 2-aminofluorene (2AF) and benzo(a)pyrene (BaP) (both from Ega-Chemie KG, Steinheim/Albuch, Federal Republic of Germany), benzo(a)pyrene trans-7,8-diol [B(a)P. 7,8-diol] and 4-nitroquinoline- $\mathrm{N}$-oxide (4NQO) (gifts of Dr. D. G. Longfellow, National Cancer Institute, Bethesda, MD), cyclophosphamide (CPA) (Endoxan, Asta-Werke AG, Bielefeld, Federal Republic of Germany), and 2-methoxy-6-chloro-9[3-(2-chloroethyl)aminopropylamino]acridine $2 \mathrm{HCl}$ (ICR 191) (Polysciences Inc., Warrington, PA). 2AF, B(a)P, and B(a)P-7,8-diol were dissolved in dimethylsulfoxide (DMSO), and sodium dichromate, CPA, ICR 191, and 4NQO in distilled water. Unfractionated cigarette smoke condensate (CSC) was prepared by aspirating two defiltered low-tar cigarettes through a disposable cigarette holder, using a water pump at a rate of $5 \mathrm{~min}$ per cigarette. The tar deposited inside the cigarette holder was eluted by rinsing with $1 \mathrm{ml}$ DMSO.

Biochemical reagents-including glucose-6-phosphate (G6P), NADP ${ }^{+}$, NADPH, and NADH-were purchased from Boehringer Mannheim GmbH (Mannheim, Federal Republic of Germany), and metabolic inhibitors-including dicumarol, pCMB, and L-thyroxine-from Sigma Chemical Co. (St. Louis, MO).

Evaluation of $\mathrm{Cr}(V I)$ reduction. For evaluating $\mathrm{Cr}(\mathrm{VI})$ reduction, varying amounts of sodium dichromate were mixed with PAM homogenates or subfractions, or with S-9 fractions of other tissues, and either combined with NADPH or NADH or incorporated into S-9 mix (representing $50-75 \%$ of the reaction mixture). S-9 mix is a NADPH-generating system composed of $8 \mathrm{mM} \mathrm{MgCl}_{2}, 33 \mathrm{mM} \mathrm{KCl}, 5 \mathrm{mM} \mathrm{G6P,} 4$ $\mathrm{mM} \mathrm{NADP}^{+}$, and $100 \mathrm{mM}$ sodium phosphate, $\mathrm{pH}$ 7.4. In some experiments, metabolic inhibitors (dicumarol, pCMB, L-thyroxine) or oxidizing agents (potassium permanganate) were also added. The final volume of all these mixtures $(0.5 \mathrm{ml})$ was obtained by adding $0.2 \mathrm{M}$ phosphatebuffered saline, $\mathrm{pH} 7.4$, unless otherwise specified.

After varying time intervals of mixing in a rotary shaker $(10 \mathrm{rpm})$ at $37^{\circ} \mathrm{C}$, the tubes were transferred into an ice-cold bath. Each mixture was then divided into two cuvettes, one of them (sample) filled with 2.25 $\mathrm{ml}$ of DPC reagent $(40 \mathrm{mg}$ of DPC in $100 \mathrm{ml}$ of $19 \%$ ethanol and $8 \%$ sulfuric acid in water) and the other one (blank) filled with $2.25 \mathrm{ml}$ of the same acid-ethanol mixture, but without DPC. After 10 to $15 \mathrm{~min}$ at room temperature, the resulting chromium-diphenylcarbazonium complex was measured at $540 \mathrm{~nm}$ in a Beckman DU7 spectrophotometer. Detailed calibration curves were drawn by testing standard solutions of untreated sodium dichromate.

Biochemical analyses. The protein concentration in ELF and in cell or tissue preparations was determined according to the protein-dye method of Bradford (25).

The enzyme activities measured in PAM included: G6PD (EC 1.1.1.49) and 6PGD (EC 1.1.1.43) (both assayed according to Rudack et al. [26]). Diaphorase activities with either NADPH or NADH as electron donors were assayed with 2,4-dichlorophenolindolphenol as electron acceptor, as described by Ernster et al. (27). All assays were carried out in duplicate and the results were expressed as mIU of enzyme activity both per $10^{6}$ PAM and per mg protein.

Evaluation of the metabolic activation or deactivation of carcinogenic and/or mutagenic compounds. The ability of PAM S-9 fractions to decrease the activity of direct-acting mutagens (i.e. sodium dichromate, ICR 191, and 4NQO) or to activate procarcinogens (i.e. 2AF, CPA, B(a)P, 
B(a)P-7,8-diol, and CSC) to mutagenic metabolites was evaluated in the Salmonella reversion test, using specially constructed strains of his- Salmonella typhimurium as targets of mutagenicity (28). The plate incorporation test was carried out as reported by Maron and Ames (28) in the case of mutagens requiring metabolic activation. In the case of directacting compounds, incorporation in plates was preceded by a liquid preincubation step $\left(1 \mathrm{~h}\right.$ at $\left.37^{\circ} \mathrm{C}\right)$ of test compounds with the complete metabolic systems.

The choice of the Salmonella strain and of the optimal concentration of each compound (in $100 \mu \mathrm{l}$ DMSO or distilled water)-which are reported in Results (see Table V)-was decided on the basis of earlier experiments with the same compounds (29) and on the results of preliminary assays. The complete metabolic system was composed of PAM S-9 fractions incorporated in a NADPH-generating system (S-9 mix), having a standard composition (28) and used at $0.5 \mathrm{ml} /$ plate. Liver S-9 fractions from Aroclor-treated Sprague-Dawley rats were also tested in order to check the efficiency of the system.

The spontaneous mutation rate of each bacterial strain (strain controls in Table V) was evaluated in the presence of the solvent of the compound tested in each experiment. The direct activity of each compound (compound controls in Table $\mathrm{V}$ ) was evaluated in the presence of S-9 mix free of S-9 fractions. All mutagenicity assays were carried out in triplicate plates.

Statistical analysis. Data are presented as the mean value \pm standard error (SE) of the mean. The significance of differences between mean values, for the various parameters investigated, was evaluated by means of Student's $t$ test.

\section{Results}

Reduction of $C r(V I)$ by ELF. BAL supernatants from 15 individuals (five nonsmokers, five exsmokers, and five smokers) were concentrated 20 -fold by freeze drying and challenged, in various amounts $(25,50,100$, and $200 \mu \mathrm{l})$, with $10 \mu \mathrm{g} \mathrm{Cr}(\mathrm{VI})(28.6 \mu \mathrm{g}$ sodium dichromate). Assuming a 1:100 dilution of ELF in BAL fluid supernatant (30), the results obtained (data not shown) allowed us to conclude that, after contact for $4 \mathrm{~h}$ at $37^{\circ} \mathrm{C}$, each $\mathrm{ml}$ of ELF reduced $23.7 \pm 15.9 \mu \mathrm{g} \mathrm{Cr}(\mathrm{VI})$ (mean $\pm \mathrm{SE}$ ). The variability observed could be mainly ascribed to the different protein concentrations of the samples tested, ranging between 85 and $1,200 \mu \mathrm{g} / \mathrm{ml}$ of the BAL fluid supernatant. The average reduction accounted for $0.6 \mu \mathrm{g} \mathrm{Cr}(\mathrm{VI}) / \mathrm{mg}$ of ELF protein. There was no significant difference in such activity between nonsmokers, exsmokers, and smokers (data not shown).

Recovery of $\mathrm{Cr}(V I)$-reducing activity in PAM subfractions. A pool of PAM recovered from five individuals was homogenized and subjected to differential centrifugation at 2,000,9,000, 20,000 and $105,000 \mathrm{~g}$. Each pellet was washed twice with 50

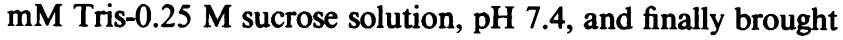
to the original volume. Although the specific $\mathrm{Cr}$ (VI)-reducing activity was similar in the different subfractions, most of the reducing ability was recovered from the supernatants (Fig. 1). A minor contribution was also supplied by materials sedimented at $2,000 \mathrm{~g}$ (nuclei and gross membrane residues), at $12,000 \mathrm{~g}$ (most mitochondria and intact lysosomes and peroxysomes), and at $20,000 \mathrm{~g}$ (light mitochondria). The amount of material recovered in the pellet at $105,000 \mathrm{~g}$, i.e. the microsomal fraction, was too low to be analyzed. However, the high recovery of activity in the corresponding supernatant (S-105 or cytosolic fraction) is likely to rule out any important contribution of microsomal fraction in the $\mathrm{Cr}(\mathrm{VI})$-reducing activity of PAM.

Requirement for co-factors and effect of heating on $\mathrm{Cr}(V I)$ reduction. Omission of S-9 mix or use of S-9 mix lacking NADP ${ }^{+}$ resulted in a considerable loss of the $\mathrm{Cr}$ (VI)-reducing ability of

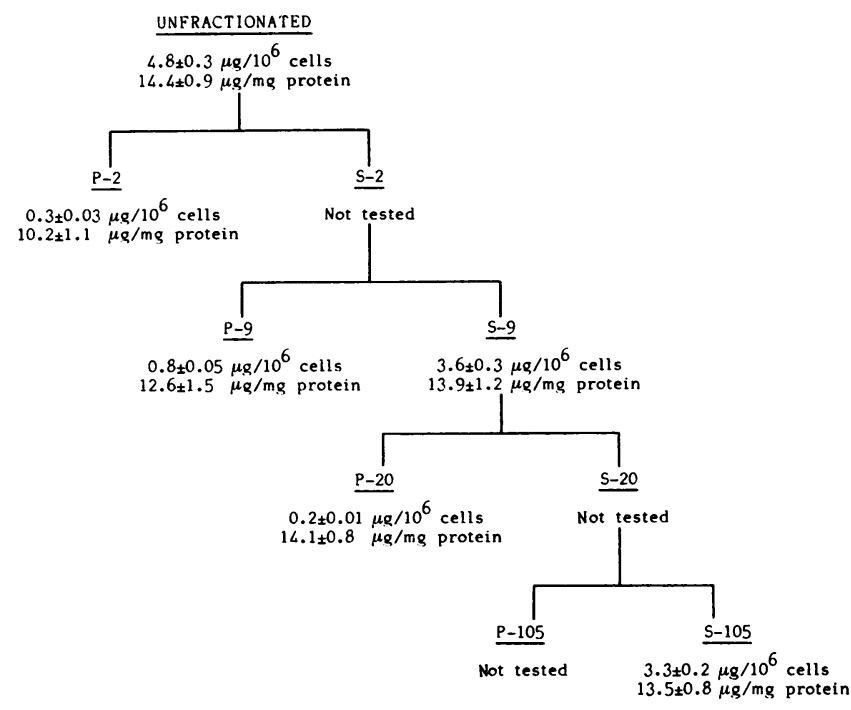

Figure 1. Amount of $\mathrm{Cr}(\mathrm{VI})$ reduced after incubation for $4 \mathrm{~h}$ at $37^{\circ} \mathrm{C}$ of sodium dichromate [28.6 $\mu \mathrm{g}$, containing $10 \mu \mathrm{g} \mathrm{Cr}(\mathrm{VI})]$ with S-9 mix (75\%, vol/vol) incorporating subfractions, obtained by differential centrifugation, at $2,000,9,000,20,000$, and $105,000 \mathrm{~g}$ of PAM homogenates pooled from five individuals (two smokers, one exsmoker, and two nonsmokers). Values are means $\pm \mathrm{SE}$ of triplicate determinations. $\mathrm{P}$, pellets; $\mathrm{S}$, supernatants.

PAM homogenates (Table I). Heating of the complete metabolic system also resulted in the elimination of the bulk of the reaction. Similar results were obtained in the presence either of equimolar NADH or of NADPH, or of the NADPH-generating system (S-9 mix).

Time dependence of $\mathrm{Cr}(\mathrm{VI})$ reduction by $\mathrm{PAM}$ homogenates. The reaction was characterized by a rapid onset, followed by a substantially decreased rate after the first $30 \mathrm{~min}$ (Fig. 2).

Substrate dependence of $\mathrm{Cr}(V I)$ reduction by $P A M$ homog. enates. As shown in Fig. 3, the efficiency of $\mathrm{Cr}(\mathrm{VI})$ reduction by PAM homogenates was linearly related to availability of sodium dichromate, until attaining a plateau. At the highest con-

Table I. Reduction of Cr(VI) by PAM Homogenates Combined with Various Metabolic Systems

\begin{tabular}{|c|c|c|c|}
\hline \multirow[b]{2}{*}{ Co-factors or treatments } & \multicolumn{3}{|c|}{$\begin{array}{l}\text { Amounts of PAM homogenates } \\
\text { (number of cells) }\end{array}$} \\
\hline & $4 \times 10^{5}$ & $2 \times 10^{5}$ & $1 \times 10^{5}$ \\
\hline 0.1 M PBS, pH 7.4 & $0.9 \pm 0.08$ & $0.6 \pm 0.12$ & $0.2 \pm 0.03$ \\
\hline Complete S-9 mix $^{*}$ & $8.5 \pm 0.96$ & $6.6 \pm 0.81$ & $3.8 \pm 0.24$ \\
\hline S-9 mix ${ }^{*}$ lacking NADP ${ }^{+}$ & $1.1 \pm 0.15$ & $0.5 \pm 0.04$ & $0.3 \pm 0.04$ \\
\hline Complete S-9 mix ${ }^{*} \ddagger$ & $0.7 \pm 0.09$ & $0.3 \pm 0.02$ & $0.1 \pm 0.01$ \\
\hline $2 \mathrm{mM}$ NADPH & $8.1 \pm 0.84$ & $5.9 \pm 0.24$ & $3.6 \pm 0.21$ \\
\hline $2 \mathrm{mM}$ NADH & $8.3 \pm 0.36$ & $6.4 \pm 0.12$ & $4.0 \pm 0.09$ \\
\hline
\end{tabular}

Amount $(\mu \mathrm{g})$ of $\mathrm{Cr}(\mathrm{VI})$ reduced after incubation for $4 \mathrm{~h}$ at $37^{\circ} \mathrm{C}$ of sodium dichromate [57.3 $\mu \mathrm{g}$, containing $20 \mu \mathrm{g} \mathrm{Cr}(\mathrm{VI})]$ with varying amounts of PAM homogenates pooled from five individuals (three smokers and two exsmokers), either in the presence or in the absence of various co-factor systems. Values are means $\pm \mathrm{SE}$ of triplicate determinations.

* Representing $50 \%$ (vol/vol) of the reaction mixture.

$¥$ Incorporating PAM homogenates heated for $5 \mathrm{~min}$ at $100^{\circ} \mathrm{C}$. 


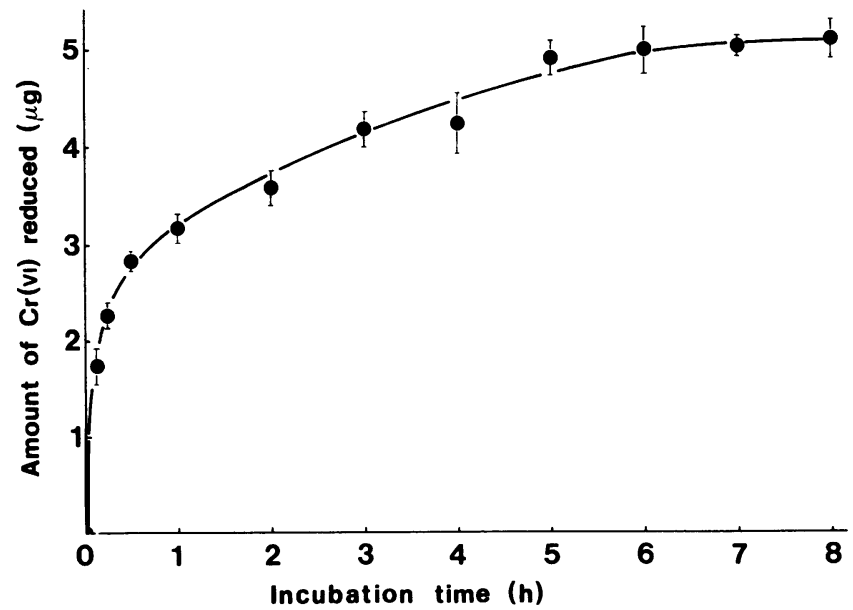

Figure 2. Amount of $\mathrm{Cr}(\mathrm{VI})$ reduced after incubation for varying time intervals of sodium dichromate [57.3 $\mu \mathrm{g}$, containing $20 \mu \mathrm{g} \mathrm{Cr}(\mathrm{VI})$ ] with S-9 mix (75\%, vol/vol) incorporating whole cell homogenates of $1 \times 10^{5}$ PAM pooled from five nonsmoking individuals. Values are means \pm SE of triplicate determinations.

centrations of $\mathrm{Cr}(\mathrm{VI})$, corresponding to 20-25 $\mathrm{mM}$ dichromate, the reaction rate tended to decrease, presumably due to inactivation of metabolizing enzymes.

Effect of $p H$ on $C r(V I)$ reduction by PAM homogenates. The $\mathrm{pH}$ optimum for $\mathrm{Cr}(\mathrm{VI})$ reduction by PAM homogenates was 6.5 (actual $\mathrm{pH}$ of the whole reaction mixture, including $\mathrm{Cr}(\mathrm{VI})$, PAM homogenates, S-9 mix, and 0.1 M PBS, at various $\mathrm{pH}$ values) (not shown).

Effect of various inhibitors on $\mathrm{Cr}(\mathrm{VI})$ reduction by $\mathrm{PAM}$ homogenates. Experiments on $\mathrm{Cr}(\mathrm{VI})$ reduction by PAM homogenates were carried out in the presence of some inhibitors (the optimal concentrations of which were assessed in preliminary assays) or of their solvents $(0.01 \mathrm{~N} \mathrm{NaOH})$. The results of a comparative assay are shown in Table II, where the values obtained in the absence of S-9 mix co-factors were subtracted in order to evaluate only the NADPH-requiring component of $\mathrm{Cr}(\mathrm{VI})$ reduction. The potent oxidizing agent $\mathrm{K}$ permanganate strongly counteracted metabolic $\mathrm{Cr}(\mathrm{VI})$ reduction. pCMB, a

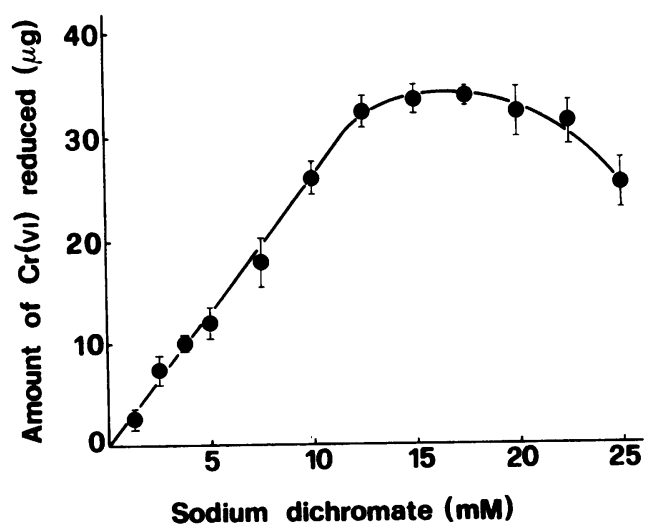

Figure 3. Amount of $\mathrm{Cr}(\mathrm{VI})$ reduced after incubation for $4 \mathrm{~h}$ at $37^{\circ} \mathrm{C}$ of varying concentrations of sodium dichromate with S-9 mix (75\%, $\mathrm{vol} / \mathrm{vol}$ ) containing whole cell homogenates of $1 \times 10^{5} \mathrm{PAM}$ pooled from five nonsmoking individuals. Values are means $\pm \mathrm{SE}$ of triplicate determinations.
Table II. Effects of Inhibitors on Cr(VI) Reduction by PAM

\begin{tabular}{llll}
\hline Inhibitor & Concentration & $\begin{array}{l}\text { Amount of Cr(VI) } \\
\text { reduced }\end{array}$ & $\begin{array}{l}\text { Inhibition of } \\
\text { reduction }\end{array}$ \\
\hline & $m M$ & $\mu g$ & $\%$ \\
NaOH (controls) & 10 & $1.37 \pm 0.16$ & - \\
Dicumarol & 0.05 & $0.84 \pm 0.11^{*}$ & 38.7 \\
pCMB & 0.1 & $0.26 \pm 0.06 \ddagger$ & 81.0 \\
L-Thyroxine & 0.1 & $1.07 \pm 0.08 \S$ & 21.9 \\
\end{tabular}

Effect of various inhibitors on $\mathrm{Cr}(\mathrm{VI})$ reduction by PAM homogenates, after incubation for $4 \mathrm{~h}$ at $37^{\circ} \mathrm{C}$ with sodium dichromate [14.3 $\mu \mathrm{g}$, containing $5 \mu \mathrm{g} \mathrm{Cr}(\mathrm{VI})]$ and $\mathrm{S}-9 \mathrm{mix}(75 \%$, vol/vol) containing homogenates of $1 \times 10^{5}$ cells pooled from five individuals (three smokers and two exsmokers). Values are means $\pm \mathrm{SE}$ of triplicate determinations.

* Significantly different from values of controls $(P<0.01)$. ¥ Significantly different from values of controls $(P<0.001)$. $\S$ Significantly different from values of controls $(P<0.05)$.

sulphydryl group reagent, was highly efficient in preventing $\mathrm{Cr}(\mathrm{VI})$ reduction. Dicumarol, a specific inhibitor of DT-diaphorase, and L-thyroxine determined a less pronounced yet significant inhibition of the reaction. The dicumarol effect, explored in the $5.5-7.5 \mathrm{pH}$ range, became progressively more evident by decreasing the $\mathrm{pH}$ of the reaction mixture (not shown).

Influence of smoking habits and of lung cancer on $\mathrm{Cr}(\mathrm{VI})$ reducing activity and on enzyme activities in human PAM. Table III summarizes the data concerning some chemical and biochemical parameters evaluated in PAM homogenates of 23 individuals, as related to their smoking habits. At equivalent numbers of cells, the amounts of total protein were significantly higher in smokers than in nonsmokers. A significant difference also existed between exsmokers and smokers $(P<0.05)$ or recent smokers (who had smoked shortly before bronchoscopy) ( $P$ $<0.01$ ). The differences between smokers and nonsmokers were even more pronounced by comparing the amounts of protein recovered in the pellet at $9,000 \mathrm{~g}$ rather than those present in unfractionated cell homogenates (data not shown).

At equivalent numbers of PAM, the two groups of smokers were significantly more efficient in reducing $\mathrm{Cr}(\mathrm{VI})$ than both nonsmokers and exsmokers $(P<0.01)$. However, no difference existed for this parameter when it was evaluated at equivalent protein concentration.

A similar picture emerged from assays of the four enzyme activities under study. In all cases the activity $/ 10^{6}$ PAM was significantly higher in the two groups of smokers than in nonsmokers. Comparison of smokers and recent smokers, respectively, with exsmokers, also yielded significant differences in almost all cases, as follows: $P<0.05$ and $P<0.05$ for G6PD; $P$ $<0.05$ and $P<0.01$ for 6PGD; $P<0.05$ and $P<0.05$ for NADH-dependent diaphorase; $P>0.05$ and $P<0.01$ for NADPH-dependent diaphorase. Again, all these enzyme activities were not significantly affected by smoking habits when they were compared at equivalent protein concentrations. The only exception was the NADPH-dependent diaphorase, the specific activity of which was significantly affected $(P<0.05)$ by recent smoking. It should be noted that both diaphorase activities, measured with NADH or NADPH as electron donors and with dichlorophenolindophenol as electron acceptor, showed little or no inhibition by dicumarol (data not shown). This indicates a 
Table III. Relationships between Smoking Habits and Metabolic Activities in PAM

\begin{tabular}{llcccc}
\hline Parameter & Unit & $\begin{array}{l}\text { Nonsmokers } \\
(n=4)\end{array}$ & $\begin{array}{l}\text { Exsmokers } \\
(n=8)\end{array}$ & $\begin{array}{l}\text { Smokers } \\
(n=6)\end{array}$ & $\begin{array}{l}\text { Recent } \\
\text { smokers** } \\
(n=5)\end{array}$ \\
\hline Protein & mg/106 PAM & $0.17 \pm 0.08$ & $0.24 \pm 0.09$ & $0.40 \pm 0.16 \ddagger$ & $0.44 \pm 0.12 \S$ \\
& $\mu \mathrm{g} / 10^{6}$ PAM & $2.4 \pm 1.12$ & $3.6 \pm 0.72$ & $5.8 \pm 1.25 \S$ & $6.3 \pm 1.09 \S$ \\
Cr(VI) reduction & $\mu \mathrm{g} / \mathrm{mg}$ protein & $14.2 \pm 6.62$ & $15.1 \pm 3.02$ & $14.6 \pm 2.80$ & $14.3 \pm 2.21$ \\
& mIU/10 PAM & $3.7 \pm 2.11$ & $5.7 \pm 3.54$ & $12.1 \pm 6.21 \ddagger$ & $12.5 \pm 4.38 \S$ \\
G6PD activity & mIU/mg protein & $21.6 \pm 12.32$ & $23.6 \pm 14.66$ & $30.2 \pm 15.49$ & $28.5 \pm 9.99$ \\
& mIU/106 PAM & $6.4 \pm 2.03$ & $7.8 \pm 3.35$ & $13.7 \pm 4.42 \ddagger$ & $13.5 \pm 2.47 \S$ \\
6PGD activity & mIU/mg protein & $37.9 \pm 12.02$ & $32.5 \pm 13.95$ & $34.2 \pm 11.03$ & $30.7 \pm 5.61$ \\
NADH-dependent & mIU/106 PAM & $9.8 \pm 3.13$ & $12.3 \pm 3.58$ & $19.8 \pm 6.17 \ddagger$ & $19.4 \pm 5.93 \ddagger$ \\
diaphorase activity & mIU/mg protein & $57.7 \pm 18.42$ & $51.1 \pm 14.87$ & $49.4 \pm 15.39$ & $44.2 \pm 13.51$ \\
NADPH-dependent & mIU/106 PAM & $2.2 \pm 0.91$ & $2.9 \pm 1.07$ & $4.2 \pm 1.29 \ddagger$ & $12.1 \pm 5.12 \S$ \\
diaphorase activity & mIU/mg protein & $13.1 \pm 5.28$ & $12.1 \pm 4.46$ & $10.6 \pm 3.25$ & $27.4 \pm 11.59 \ddagger$ \\
\hline
\end{tabular}

Influence of smoking habits on the protein concentration and on some enzyme activities of human PAM homogenates and on their ability to reduce $\mathrm{Cr}(\mathrm{VI})$ [28.6 $\mu \mathrm{g}$ of sodium dichromate, corresponding to $10 \mu \mathrm{g} \mathrm{Cr}(\mathrm{VI})$ ] in the presence of $\mathrm{S}-9 \mathrm{mix}\left(75 \%\right.$, vol/vol) within $4 \mathrm{~h}$ at $37^{\circ} \mathrm{C}$.

* Smoking 1-3 cigarettes also during the last $2 \mathrm{~h}$ before BAL. ¥ Significantly higher than values of nonsmokers $(P<0.05)$. $\S$ Significantly higher than values of nonsmokers $(P<0.01)$.

low contribution of DT-diaphorase to the total diaphorase activities in PAM homogenates.

The 11 cases of lung cancer were all smokers or exsmokers. Within each of these groups, the $\mathrm{Cr}$ (VI)-reducing activity, either at equivalent PAM number or at equivalent protein concentration, did not significantly differ between cancer and noncancer patients (data not shown).

Inducibility by Aroclor 1254 of $\mathrm{Cr}(\mathrm{VI})$-reducing activity in rat $P A M$. In general, efficiency of $\mathrm{Cr}(\mathrm{VI})$ reduction by rat $\mathrm{PAM}$ was of the same order of magnitude as reduction by human PAM, although no comparative assay was carried out. In order to check the inducibility of the process by the well-known enzyme stimulator Aroclor 1254, PAM homogenates pooled from 20 control rats (receiving corn oil only) and from 20 Aroclor-treated rats were comparatively assayed for their $\mathrm{Cr}$ (VI)-reducing activity.

After incubation (at $37^{\circ} \mathrm{C}$ for $4 \mathrm{~h}$ ) of $14.3 \mu \mathrm{g}$ sodium dichromate [containing $5 \mu \mathrm{g} \mathrm{Cr}$ (VI)] with PAM homogenates (obtained from $2 \times 10^{5}$ cells), in the presence of S-9 mix co-factors, $1.33 \pm 0.09 \mu \mathrm{g} \mathrm{Cr}$ (VI) was reduced by the preparations of untreated rats vs. $1.48 \pm 0.09 \mu \mathrm{g}$ for Aroclor-treated rats (means $\pm \mathrm{SE}$ of quintuplicate determinations). Such difference, although not pronounced, was statistically significant $(P<0.05)$. It was not related to the protein content of PAM homogenates, which was rather similar in the two groups $\left(0.144\right.$ and $0.137 \mathrm{mg} / 10^{6}$ cells, respectively).

A similar difference between untreated and Aroclor-treated rats was confirmed in a subsequent experiment, in which $\mathrm{Cr}$ (VI) was challenged in duplicate, under the same conditions, with varying amounts of PAM homogenates (corresponding to 4, 2, 1 , and $0.5 \times 10^{5}$ cells) (data not shown).

Specific $\mathrm{Cr}(\mathrm{VI})$-reducing activity of $S-9$ fractions of human $P A M$, as compared with other human or rat preparations. The comparison of $\mathrm{Cr}(\mathrm{VI})$-reducing activity of PAM and of tissue (lung or liver) preparations is rather complex, because the concentration of the tissue in a homogenate is expressed as weight per volume, rather than as number of cells per volume. Therefore, comparisons were made at equivalent protein concentration of PAM or tissue S-9 fractions. To this purpose, samples of human S-12 or rat S-9 fractions were accurately normalized in their protein content and then comparatively assayed for their $\mathrm{Cr}$ (VI)-reducing ability in the presence of S-9 mix co-factors.

The results shown in Table IV demonstrate that BSA was ineffective in reducing $\mathrm{Cr}$ (VI), whereas PAM S-9 fractions were the most effective, with significant differences as compared with S-12 fractions prepared from a mixed cell population either of human bronchial tree or of lung peripheral parenchyma, or of S-9 fractions of rat lung or liver. In this comparison it should be noted that bronchial tree and lung peripheral parenchyma samples were obtained from the same surgery patients, whereas PAM were obtained from other individuals. The same rank of activity was confirmed in two additional experiments.

Table IV. Specific Activities of Various Cell Preparations in Reducing $\mathrm{Cr}(V I)$

\begin{tabular}{lc}
\hline Test sample & $\begin{array}{l}\text { Amount of } \operatorname{Cr}(\mathrm{VI}) \\
\text { reduced }\end{array}$ \\
\hline BSA & $\mu g / m g$ protein \\
Human alveolar macrophages & 0 \\
Human bronchial tree & $14.4 \pm 0.7$ \\
Human lung peripheral parenchyma & $9.1 \pm 0.3^{*}$ \\
Rat lung peripheral parenchyma & $8.3 \pm 0.4^{*}$ \\
Rat liver & $10.2 \pm 0.4^{*}$ \\
\hline
\end{tabular}

Reduction of $\mathrm{Cr}(\mathrm{VI})$ after incubation for $4 \mathrm{~h}$ at $37^{\circ} \mathrm{C}$ of sodium dichromate [28.6 $\mu \mathrm{g}$, containing $10 \mu \mathrm{g} \mathrm{Cr}(\mathrm{VI})]$ with $\mathrm{S}-9 \mathrm{mix}(75 \%$, vol/ vol) containing either BSA or S-9 (or S-12) fractions from human or rat cell homogenates (each of them pooled from five individuals or animals). Values are means $\pm \mathrm{SE}$ of triplicate determinations (see the text).

* Significantly lower as compared with values of human PAM $(P$ $<0.001$ ).

$\ddagger$ Significantly lower as compared with values of human PAM ( $P$ $<0.01$ ). 
Effect of PAM S-9 fractions on the mutagenicity of $\mathrm{Cr}(\mathrm{VI})$ and of other compounds. The ability of PAM S-9 fractions in reducing $\mathrm{Cr}(\mathrm{VI})$ was confirmed in the Ames reversion test. In fact, the mutagenicity of dichromate to both strains TA100 and TA 102 of $S$. typhimurium was markedly decreased in the presence of these PAM preparations, as shown in Table $\mathrm{V}$ and as confirmed in several separate experiments. Obviously, although demonstrating the same trend, the data obtained in this biological test system and those resulting from colorimetric analyses cannot be compared from a quantitative point of view. This is also true because, in the mutagenicity test system, $\mathrm{Cr}(\mathrm{VI})$ and PAM preparations were preincubated for $60 \mathrm{~min}$ before plating with bacteria, but some additional metabolic reduction might have occurred in the soft agar overlay, depending on the rapidity of $\mathrm{Cr}(\mathrm{VI})$ in penetrating into cells.

Table V also shows the ability of PAM S-9 fractions to decrease the activity of two direct-acting mutagens (4NQO and ICR 191) and in activating five procarcinogens [B(a)P, B(a)P7,8-diol, 2AF, CSC, and CPA]. Liver S-9 fractions from Aroclortreated rats were also assayed in order to check the efficiency of the system. PAM preparations, at the maximum concentration tested (corresponding to $1 \times 10^{5}$ cells/plate), failed to convert procarcinogens into mutagenic metabolites. In contrast, a significant decrease in mutagenic activity, although less pronounced than in the case of $\mathrm{Cr}(\mathrm{VI})$, was produced by PAM S-9 fractions on the antitumor compound ICR 191.

\section{Discussion}

The results obtained in this study provide first evidence that the epithelial-lining fluid recovered from the extracellular environment of terminal airways has a detectable activity in reducing $\mathrm{Cr}$ (VI). In addition, as shown both by colorimetric analyses and in the mutagenicity test system, reduction of chromium was particularly efficient in PAM homogenates and in their subcellular fractions. In fact, at equivalent protein concentration the specific reducing activity of human PAM was by far higher than that displayed by ELF. Moreover, it significantly exceeded the reducing capacity of mixed-cell populations from human lung peripheral parenchyma or bronchial tree, or from rat lung or liver cells. All these preparations are capable of reducing, to a variable extent, the mutagenicity of $\operatorname{Cr}(\mathrm{VI})(6,18)$.

Reduction of chromium by PAM was afforded by various subcellular fractions, but mainly by cytosolic components. Most of this activity was thermolabile and required the supply of exogenous NADH or NADPH, either as such or produced by a NADPH-generating system (S-9 mix). These patterns demonstrate the involvement of enzyme-catalyzed mechanisms in the intracellular chromium reduction, as further supported by the finding that the efficiency of the reaction was directly related to the amount of the substrate $[\mathrm{Cr}(\mathrm{VI})]$ until reaching a plateau, indicating a saturation phenomenon.

The reaction was better achieved in a slightly acidic environment and was counteracted not only by the oxidizing agent permanganate but also by some metabolic inhibitors, the most efficient of which was the sulphydryl group reagent pCMB. Some inhibition was also obtained with L-thyroxine and dicumarol, a specific inhibitor of DT-diaphorase (27), suggesting that this enzyme activity, which had been so far demonstrated to afford detoxification of some organic compounds (27, 31, 32), can also give a partial contribution to reduction of $\mathrm{Cr}(\mathrm{VI})$ in human PAM.

Due to the inability of $\mathrm{Cr}$ (III) to permeate mammalian cell membranes $(3,5)$, reduction of $\mathrm{Cr}(\mathrm{VI})$ by ELF appears to represent a first defensive barrier against inhaled chromium, based on oxido-reductive mechanisms. A further, more important barrier is likely to be represented by the enzyme-catalyzed reduction of $\mathrm{Cr}$ (VI) in the cytoplasm of PAM, the multiplication and phagocytosis of which is stimulated by chromium itself (2123). As extensively discussed (6), irrespective of the valence of chromium bound to DNA, the species resulting from $\mathrm{Cr}$ (VI) reduction in the cytoplasm [ $\mathrm{Cr}(\mathrm{III})$ and $\mathrm{Cr}(\mathrm{V})]$ are expected to be trapped outside the cell nucleus. In addition to this detoxification process, phagocytosis by PAM should lead to sequestration of $\mathrm{Cr}$ (VI) in a virtually irreversible way, due to the extremely long life span of these cells (months to years) (33) and

Table V. Effect of Preincubation $\left(30\right.$ min at $\left.37^{\circ} \mathrm{C}\right)$ of PAM S-9 Fractions with Direct-acting Mutagens (Na Dichromate, $4 N Q O$, and ICR 191) or with Promutagens (B(a)P, B(a)P-7,8-diol, $2 A F, C S C$, and CPA) on Their Activity in the Ames Reversion Test

\begin{tabular}{|c|c|c|c|c|c|}
\hline \multirow[b]{3}{*}{ Compound ( $\mu g /$ plate) } & \multirow[b]{3}{*}{$\begin{array}{l}\text { Salmonella } \\
\text { strain }\end{array}$} & \multicolumn{4}{|c|}{ Number of revertants (mean $\pm \mathrm{SE}$ ) } \\
\hline & & \multicolumn{2}{|c|}{ Without S-9 fractions } & \multicolumn{2}{|l|}{ With S-9 fractions } \\
\hline & & $\begin{array}{l}\text { Strain } \\
\text { controls }\end{array}$ & $\begin{array}{l}\text { Compound } \\
\text { controls }\end{array}$ & $\begin{array}{l}\text { Human PAM } \\
\left(200 \mu 1=1 \times 10^{6} \text { cells }\right)\end{array}$ & $\begin{array}{l}\text { Rat liver (Aroclor) } \\
(50 \mu \mathrm{l}=12.5 \mathrm{mg})\end{array}$ \\
\hline Na dichromate (30) & TA102 & $219 \pm 27$ & $1,366 \pm 58$ & $889 \pm 73 \S$ & $351 \pm 42 \S$ \\
\hline Na dichromate (30) & TA100 & $136 \pm 15$ & $821 \pm 22$ & $504 \pm 36 \S$ & $147 \pm 15 \S$ \\
\hline 4NQO $(0.5)$ & TA100 & $136 \pm 15$ & $2,252 \pm 135$ & $2,110 \pm 132$ & $328 \pm 36 \S$ \\
\hline $\mathrm{B}(\mathrm{a}) \mathrm{P}(5)$ & TA100 & $136 \pm 15$ & $131 \pm 28$ & $137 \pm 12$ & $682 \pm 17 \S$ \\
\hline B(a)P-7,8-diol (10) & TA100 & $136 \pm 15$ & $143 \pm 9$ & $160 \pm 21$ & Toxic \\
\hline $2 \mathrm{AF}(20)$ & TA98 & $23 \pm 6$ & $47 \pm 5$ & $51 \pm 14$ & $2,501 \pm 48 \S$ \\
\hline $\operatorname{CsC}\left({ }^{*}\right)$ & TA98 & $23 \pm 6$ & $25 \pm 2$ & $21 \pm 8$ & $449 \pm 11 \S$ \\
\hline CPA $(4,000)$ & TA1535 & $13 \pm 3$ & $114 \pm 24$ & $102 \pm 15$ & $916 \pm 82 \S$ \\
\hline ICR191 (2) & TA1537 & $11 \pm 4$ & $2,454 \pm 39$ & $2,085 \pm 106 \ddagger$ & $26 \pm 5 \S$ \\
\hline
\end{tabular}

* Amount corresponding to the tar recovered from 0.2 cigarettes. $¥$ Significantly different from values of compound controls $(P<0.01) . \quad \S$ Significantly different from values of compound controls $(P<0.001)$. 
to their very efficient removal by the muco-ciliatory escalator, accounting for one- to five-million cells per hour leaving the lung and being either expectorated or swallowed (34).

These findings give further support to the view that the pulmonary carcinogenesis by chromium is subjected to threshold phenomena. In fact, it is evident that inhaled $\mathrm{Cr}$ (VI) must exceed not only the aspecific defense mechanisms of the respiratory tract, but also the reducing ability of ELF and the specific metabolic pathways reducing chromium in the cytoplasm of both sweeping cells (PAM) and of target cells. Such a conclusion is in agreement with the results of an extensive intratracheal carcinogenicity study performed with sodium dichromate and calcium chromate in solution, which showed a weak carcinogenic effect only in the respiratory tract, at the highest doses tested and in animals treated with single, weekly doses rather than in fractionated, daily doses (22). These patterns-i.e., carcinogenicity only at the implant site, at the highest dose, without doseresponse effects, and following massive administrations rather than repeated, fractionated administrations-meet the criteria suggested for ascribing a threshold character to the carcinogenic response (8) and are supported by the underlying detoxification mechanisms.

Experiments aiming at assessing the inducibility of $\mathrm{Cr}(\mathrm{VI})$ reduction by PAM preparations showed that the PCB Aroclor 1254 , which is a potent and wide-spectrum inducer of both microsomal (35) and cytosolic (7) enzymes, stimulated in rats a slight yet significant increase in activity.

Irrespective of the clinical diagnosis, smoking habits had significant effects on the $\mathrm{Cr}(\mathrm{VI})$-reducing activity of alveolar macrophages and on the biochemical parameters monitored. Cigarette smoke is known to elicit a variety of effects on PAM, including a considerable increase in the number of cells, an enlargement in their mean diameter, formation of cytoplasmic inclusions containing pigmented residues of the smoke, as well as a wide range of biochemical alterations $(19,36)$. In PAM preparations of smokers, especially if smoking shortly before bronchoalveolar lavage, we found an increased ability to reduce $\mathrm{Cr}$ (VI) and a stimulation of enzyme activities, such as G6PD and 6PGD, and NADPH- and NADH-dependent diaphorases.

In any case, with the exception of NADPH-dependent diaphorase (the specific activity of which was found to be stimulated by recent smoke), all the differences observed between nonsmokers, exsmokers, and smokers were settled when comparisons were made in terms of specific activity, i.e. at equivalent protein concentration. Accordingly, the enhanced activities measured at equivalent number of cells can be ascribed to the increased amounts of protein consequent to cigarette smoking rather than to specific metabolic inductions. Nevertheless, for practical purposes it is important that the increase both in the number of macrophages (which also in this study was confirmed by a considerably higher recovery of cells by bronchoalveolar lavage) and in their protein content are expected to result in a magnified phagocytosis and reduction of $\mathrm{Cr}(\mathrm{VI})$ in PAM of smokers.

This study gives further support to the view that alveolar macrophages can play some role in metabolizing chemical carcinogens, either in the sense of activation or of deactivation. These cells contain low yet detectable amounts of cytochromes P-450 $(37,38)$ and their aryl hydrocarbon hydroxylase activity appears to be inducible in situ by cigarette smoke $(39,40)$. Typical procarcinogens or their proximate metabolites, such as $B(a) P$ and $\mathrm{B}(\mathrm{a}) \mathrm{P}-7,8-d i o l$, were found to induce an increase in the number of mutants after co-incubation of cultured human (41) or rabbit (42) PAM with V-79 cells. These polycyclic aromatic hydrocarbons and other procarcinogens failed to elicit any mutagenic response in our experimental system, involving co-incubation of a suitable $S$. typhimurium strain with PAM S-9 fractions. A negative result was also reported in another laboratory, by testing 2AAF in a chamber mutagenicity assay using rabbit PAM as metabolizing system and $S$. typhimurium as genetic target (38). It should be mentioned that the amount of cells that we could use for the preparation of PAM S-9 fractions was quite low, as compared with the rodent liver S-9 fractions, which are generally used in the Ames reversion test and are obtained from 25\% (wt/vol) homogenates. Nevertheless, these preparations were capable of reducing the mutagenicity of sodium dichromate and, to a lower yet significant extent, that of ICR191 antitumor compound. Another study showed that incubation with cultured rabbit PAM of diesel particles containing nitroaromatics, such as 1-nitropyrene, results in a considerable loss of mutagenicity for S. typhimurium (43).

Thus, on the whole, it is apparent that alveolar macrophages not only represent an important aspecific defense mechanismby engulfing and sequestering particulates carrying mutagenic/ carcinogenic agents-but in some cases they also possess metabolic systems competent to achieve the intracellular detoxification of direct-acting chemicals.

\section{Acknowledgments}

We thank Drs. C. Giuntini for supplying preparations of human bronchial tree and of peripheral lung parenchyma, B. Balbi for collaboration in PAM collection, A. Morelli for biochemical analyses, P. Zanacchi, M. Astengo and C. Basso for mutagenicity assays.

This study was supported by CNR (Special Projects "Preventive and Rehabilitative Medicine", Subproject "Degenerative Diseases") and by IHF Chromium Chemicals Environmental Health and Safety Committee.

\section{References}

1. International Agency for Research on Cancer. 1980. Chromium and chromium compounds. In IARC Monographs for the Evaluation of the Carcinogenic Risk of Chemicals to Humans. Some Metals and Metallic Compounds. IARC (World Health Organization), Lyon, France. 23:205-323.

2. International Agency for Research on Cancer. 1982. Chromium and certain chromium compounds. In IARC Monographs for the Evaluation of the Carcinogenic Risk of Chemicals to Humans. IARC (World Health Organization), Lyon, France. 1-29, Suppl. 4:91-93.

3. Levis, A. G., and V. Bianchi. 1982. Mutagenic and cytogenetic effects of chromium compounds. In Biological and Environmental Effects of Chromium. S. Langård, editor. Elsevier Biomedical Press, New York. 171-208.

4. Petrilli, F. L., and S. De Flora. 1982. Interpretations on chromium mutagenicity and carcinogenicity. In Mutagens in Our Environment. M. Sorsa and H. Vainio, editors. Alan R. Liss, Inc., New York. 453464.

5. Langård, S. 1982. Absorption, transport, and excretion of chromium in man and animals. In Biological and Environmental Effects of Chromium. S. Langård, editor. Elsevier Biomedical Press, New York. 149-159.

6. Petrilli, F. L., A. Camoirano, C. Bennicelli, P. Zanacchi, M. Astengo, and S. De Flora. 1985. Specificity and inducibility of the metabolic reduction of chromium (VI) mutagenicity by subcellular fractions of rat tissues. Cancer Res. 45:3179-3187.

7. De Flora, S., A. Morelli, C. Basso, M. Romano, D. Serra, and A. 
De Flora. 1985. Prominent role of DT-diaphorase as a cellular mechanism reducing chromium (VI) and reverting its mutagenicity. Cancer Res. 45: 3188-3196.

8. De Flora, S. 1985. Possible thresholds in genotoxicity and carcinogenicity resulting from detoxication mechanisms. Ann. Am. Conf. Ind. Hyg. 12:145-155.

9. Korallus, U., C. Harzdorf, and J. Lewalter. 1984. Experimental bases for ascorbic acid therapy of poisoning by hexavalent chromium compounds. Int. Arch. Occup. Environ. Health. 53:247-256.

10. Gray, S. J., and K. Sterling. 1950. Tagging of red cells and plasma proteins with radioactive chromium. J. Clin. Invest. 29:1604-1613.

11. Petrilli, F. L., and S. De Flora. 1978. Metabolic deactivation of hexavalent chromium mutagenicity. Mutation Res. 54:139-147.

12. De Flora, S. 1982. Biotransformation and interaction of chemicals as modulators of mutagenicity and carcinogenicity. In Environmental Mutagens and Carcinogens. T. Sugimura, S. Kondo, and H. Takebe, editors. Alan R. Liss, Inc., New York. 527-541.

13. Donaldson, R. M., and R. F. Barreras. 1966. Intestinal absorption of trace quantities of chromium. J. Lab. Clin. Med. 68:484-493.

14. De Flora, S. 1978. Metabolic deactivation of mutagens in the Salmonella/microsome test. Nature (Lond.). 271:455-456.

15. Ryberg, D., and J. Alexander. 1984. Inhibitory action of hexavalent chromium $(\mathrm{Cr}(\mathrm{VI}))$ on the mitochondrial respiration and a possible coupling to the reduction of $\mathrm{Cr}(\mathrm{VI})$. Biochem. Pharmacol. 33:24612466.

16. Garcia, J. D., and K. W. Jennette. 1981. Electron-transport cytochrome P-450 system is involved in the microsomal metabolism of the carcinogen chromate. J. Inorg. Biochem. 14:281-295.

17. Alexander, J., D. Ryberg, and A. Mikalsen. 1985. Microsomal reduction of chromate $\mathrm{Cr}(\mathrm{VI})$. Proc. 4th Intern. Conf. Environ. Mutagens, Stockholm. 117. (Abstr.)

18. De Flora, S., C. Bennicelli, P. Zanacchi, A. Camoirano, S. Petruzzelli, and C. Giuntini. 1984. Metabolic activation and deactivation of mutagens by preparations of human lung parenchyma and bronchial tree. Mutation Res. 139:9-14.

19. Gardner, D. E. 1984. Alterations in macrophage functions by environmental chemicals. Environ. Health Perspect. 55:343-358.

20. Stettler, L. E., D. H. Groth, and G. R. Mackay. 1977. Identification of stainless steel welding fume particulates in human lung and environmental samples using electron probe microanalysis. Am. Ind. Hyg. Assoc. J. 38:76-82.

21. Camner, P., A. Johansson, and M. Lundborg. 1978. Alveolar macrophages in rabbits exposed to nickel dust. Environ. Res. 16:226235.

22. Steinhoff, D. 1984. Carcinogenicity study with sodium dichromate in rats. Cancer Detect. Prev. 7:(abstract No.) 33:006.

23. Glaser, U., D. Hochrainer, H. Klöppel, and H. Kuhnen. 1985. Low level chromium(VI) inhalation effects on alveolar macrophages and immune functions in Wistar rats. Arch. Toxicol. 57:250-256.

24. Rossi, G. A., O. Sacco, E. Cosulich, G. Damiani, G. Corte, A. Bargellesi, and C. Ravazzoni. 1984. Pulmonary sarcoidosis: excess of helper $T$ lymphocytes and $T$ cell subset imbalance at sites of disease activity. Thorax. 39:143-149.

25. Bradford, M. 1976. A rapid and sensitive method for the quantitation of microgram quantities of protein utilizing the principle of protein-dye binding. Anal. Biochem. 72:248-254.

26. Rudack, D., E. M. Chisholm, and D. Holten. 1971. Rat liver glucose 6-phosphate dehydrogenase. Regulation by carbohydrate, diet and insulin. J. Biol. Chem. 246:1249-1254.

27. Ernster, L., L. Danielson, and M. Ljunggren. 1962. DT-diaphorase. I) Purification from the soluble fraction of rat-liver cytoplasm, and properties. Biochim. Biophys. Acta. 58:171-188.

28. Maron, D. M., and B. N. Ames. 1983. Revised methods for the Salmonella mutagenicity test. Mutation Res. 113:173-215.

29. De Flora, S., P. Zanacchi, A. Camoirano, C. Bennicelli, and G. Badolati. 1983. Genotoxic activity and potency of 135 compounds in the Ames reversion test and in a bacterial DNA-repair test. Mutation Res. 133:161-198.

30. Crystal, R. G., P. B. Bitterman, S. I. Rennard, A. J. Hance, and B. A. Keogh. 1984. Interstitial lung disease of unknown cause: disorders characterized by chronic inflammation of the lower respiratory tract. $N$. Engl. J. Med. 310:154-166.

31. Lind, C., P. Hochstein, and L. Ernster. 1982. DT-diaphorase as a quinone reductase: a cellular control device against semiquinone and superoxide radical formation. Arch. Biochem. Biophys. 216:178-185.

32. Huang, M. T., G. T. Miwa, and A. Y. H. Lu. 1979. Rat liver cytosolic azoreductase. Purification and characterization. J. Biol. Chem. 254:3930-3934.

33. Hunninghake, G. W., J. E. Gadek, S. V. Szapiel, I. J. Strumpf, O. Kawanami, V. J. Ferrans, B. A. Keogh, and R. G. Crystal. 1980. The human alveolar macrophage. Methods Cell Biol. 21A:95-105.

34. Green; G. M., G. J. Jakab, R. B. Low, and G. E. Davis. 1977. Defense mechanisms of the respiratory membrane. Am. Rev. Respir. Dis. 115:479-514.

35. Alvares, A. P., D. R. Bickers, and A. Kappas. 1973. Polychlorinated biphenyls: a new type of inducer of cytochrome P-448 in the liver. Proc. Natl. Acad. Sci. USA. 70:1321-1325.

36. Matulionis, D. H., and H. H. Traurig. 1977. In situ response of the lung macrophages and hydrolase activity to cigarette smoke. Lab. Invest. 37:314-326.

37. Fisher, A. B., G. A. Huber, and L. Furia. 1977. Cytochrome P450 content and mixed-function oxidation by microsomes from rabbit alveolar macrophages. J. Lab. Clin. Med. 90:101-108.

38. Aune, T., T. R. Devereux, and K. Tveito. 1985. Metabolism of 2-acetylaminofluorene by Clara cells, type II cells and alveolar macrophages isolated from rabbit lung, and use of a new chamber incubation mutagenicity test system. Cell Biol. Toxicol. 1:109-122.

39. Cantrell, E. T., G. E. Warr, D. L. Busbee, and R. R. Martin. 1973. Induction of $\mathrm{AHH}$ in human pulmonary alveolar macrophages by cigarette smoking. J. Clin. Invest. 52:1881-1884.

40. McLemore, T. L., R. R. Martin, D. L. Busbee, R. C. Richie, R. R. Springer, K. L. Toppell, and E. T. Cantrell. 1977. Aryl hydrocarbon hydroxylase activity in pulmonary macrophages and lymphocytes from lung cancer and noncancer patients. Cancer Res. 37:1175-1181.

41. Harris, C. C., I. C. Hsu, G. D. Stoner, B. F. Trump, and J. K. Selkirk. 1978. Human pulmonary alveolar macrophages metabolize benzo(a)pyrene to proximate and ultimate mutagens. Nature (Lond.). 272:633-634.

42. Romert, L., and D. Jenssen. 1983. Rabbit alveolar macrophagemediated mutagenesis of polycyclic aromatic hydrocarbons in V79 Chinese hamster cells. Mutation Res. 111:245-252.

43. King, L. C., K. Loud, S. B. Tejada, M. J. Kohan, and J. Lewtas. 1983. Evaluation of the release of mutagens and 1-nitropyrene from diesel particles in the presence of lung macrophages in culture. Environ. Mutagenesis. 5:577-588. 